\title{
Simulation of Government Policy Impact on Food Security and Poverty in Aceh
}

\author{
${ }^{1}$ ZAKIAH, ${ }^{2}$ FAUZAN \\ ${ }^{1}$ Agriculture Faculty, Syiah Kuala University, Jl. Tgk hasan Krueng kalee no 3 darussalam, \\ ${ }^{2}$ STIE Amanat Bangsa, Jl. Merdeka Barat No 1 B Lhokseumawe \\ email: 12zakiahhasan73@gmail.com; ${ }^{2}$ fauzanbris@gmail.com
}

\begin{abstract}
Insufficient food availability causes most of food need in Indonesia fulfilled by import. This study aims to analyze the influence of government policy on food security and poverty in Aceh. It uses panel data of 21 regencies in 2007 to 2016 which were selected based on agricultural sector. Data were analyzed using 2 SLS method. Historical simulations are used to simulate food security in Aceh. The analysis showed that a single policy alone, for example to increase government spending, would not effective to increase food security and reduce poverty in Aceh. Combination of policies in increasing government spending on food crops sub-sector, followed by stabilization on food price is the most effective way to improve food security and reduce poverty. To increase farmer's capital assistance, especially for poor farmers, government may bear some of the cost of production to produce food by providing working capital assistance in the form of a special program financing.
\end{abstract}

Keywords: food security, poverty, simulation

\section{Introduction}

Insufficient food availability causes most of food needs in Indonesia fulfilled by import. The price of imported food is sometimes relatively lower than domestic ones and it makes local farmers have difficulties in competing to increase their production. Moreover, food farmers in Indonesia are generally poor and live with limited capital. If the government is not serious in determining the policies for farmers' welfare, the availability of food will not be enough to meet the increasing needs of population.

Successful development in agriculture, in addition to increasing agricultural production and food security, also has a strong relationship with poverty reduction. This is due to the fact that the increased production is not only affecting the increase of farmer's income, but also play a part in maintaining food price stability so that the real income of all society will also increase. Timmer (1995) states that increased agricultural production and farmer income will encourage better nutritional adequacy and enhance the investment in other sectors. Growth in agricultural sector is also able to stimulate demand for infrastructure and increase tax revenues, capital accumulation, and interaction between farmers and marketing channel agents (Irz et al., 2001).

Ravallion and Datt (1996) suggest that the agricultural sector is a highly effective sector of reducing rural poverty in India. According to their research, 85 percent poverty reduction in India is the impact of growth in agricultural sector. The development of agricultural sector not only reduces rural poverty but also in urban areas. According to Thomson (2004), between agriculture and poverty there are four mechanisms, namely (1) the success of agricultural development has a direct impact on the increase of rural income; (2) the successful development of agriculture impact on the decrease of food prices for consumption needs both in urban and rural areas; (3) agriculture contributes to the development of other sectors, such as industry; (4) agriculture also opens employment opportunities in manufacturing and services. Growth in agricultural sector will have a major impact on welfare compared

Received: January 29, 2018, Revision: July 11, 2018, Accepted: December 17, 2018

Print ISSN: 0215-8175; Online ISSN: 2303-2499. DOI: http://dx.doi.org/10.29313/mimbar.v34i2.3451.301-310

Accredited B based on the decree No.040/P/2014, valid on February, 18, 2014 until February, 18, 2019. Indexed by DOAJ, Sinta, IPI 
to the growth of non-agricultural sector, especially in poor population of about 20 percent of the whole population (World Bank, 2007).

The government must pay serious attention to the efforts of increasing farmers' income. It is feared that if farmers as producers do not get a decent income from their farming, they will not be interested in managing their businesses anymore. This will cause greater land transfer from agriculture to non-agriculture. If this happens, then in the long run our food insecurity will be even greater. Indonesia will increasingly depend on imported food; while on the other hand, we are an agricultural country. Therefore, government policies, especially in agricultural and trade sectors, should stand side by side with farmers; especially since fiscal decentralization the regions have the authority to manage their own regional revenues and expenditures.

Government spending in agricultural sector is crucial to encourage agricultural development and rural economic growth and reduce poverty (Mogues et al. 2012; Rada et al. 2011). Moreover, more than 60 percent of poverty in Indonesia is in rural areas, and most of them are farmers. Farmers in villages are generally poor because they only have very little land, such as what happens in Sumbawa, where 84 percent of poverty is caused by topography and small asset ownership, including agricultural asset (Ibrahim et.al, 2016). The same thing happens in Aceh where poverty in the village reached 19.11 percent, while in the city is only 10.82 percent. In total, until 2017, number of poor people in Aceh was 15.92 percent and still higher than the average percentage of poverty in Indonesia (10.12 percent) (http://www.bps.co.id). It shows that the development in Aceh has not succeeded in reducing poverty.

The development so far has not yet succeeded in narrowing the gap between urban and rural areas. Likewise, with the research results of Suryahadi and Hadiwidjaya (2011), the phenomenon of poverty in Indonesia is more concentrated in rural areas, particularly in agricultural sector. The food crop sub-sector has the largest number of poor farmers in agricultural sector, i.e. 108,299 people in Aceh and 3,795,976 in Indonesia (information and data center of Indonesian agricultural ministry/ Pusdatin Kementan RI, 2015).

Programs to alleviate poverty and maintain food security should focus more on efforts to advance rural areas, in addition to urban areas. Moreover, Siregar and Dwi (2008) stated that after going through a crisis period, economic growth in Indonesia, despite showing an increasing trend, was actually stagnant due to the relatively large number of inequality of economic activities between regions. Therefore, the economy in rural areas must be empowered to be able to take a major role in alleviating poverty. Anriquez (2007); Christiaensen et al. (2011), argues that in developing rural areas and reducing poverty, agricultural sector is still a starting point that should be considered by the government. Agricultural development is also quite effective in reducing poverty in low-income countries.

Food security is a link between three components, namely (1) food availability and stability; (2) the ease of obtaining food accessibility, physically and economically; (3) food utilization. The food to consume must be sufficient in number, safe, and have nutritional value to meet energy needs to be able to live an active, healthy and productive life FAO (1996); Timmer (2004). According to law No. 18 of 2012, food security is a condition of fulfilling food needs for the country as a whole and to each individual, reflected in the availability of adequate food both in terms of quantity and quality, guaranteed security, diverse, nutritional, evenly distributed and affordable, and not in the contrary to beliefs, religion, and culture.

There are three important subsystems that affect food security, namely: (1) the food supply subsystem, including arrangements for regulating the stability and sustainability of the food production and supply processes from local production, reserves, and imports. Food supply is very dependent on the level of food production, which apply to all kind of food needs especially rice; (2) food affordability subsystem, including arrangements to ensure that people are able to access food both physically and economically. Physically means it is reachable and can be bought anywhere and at any time, while economically means people can buy the food at an affordable price. Therefore, the stability of food prices must be a great concern of the government, especially for the basic needs such as rice; (3) the food utilization subsystem, including how to manage food from regional level to household level and ensures that each individual can obtain food in quantity, quality, diversity, and security he/she desires. 
According to some results of research on food security, it turns out that the concept of food security has a very broad aspect. Data, indicators, and variables used by researchers to measure food security are widely varied depending on the objectives and interests of the study. The indicators of food security can be in the form of major food price fluctuations, food production, food availability, conditions of food consumption, nutritional status, ratio of stock to consumption, proportion of food expenditure, expected food pattern scores, level of government food reserves, ability to carry out food stocks, indexes food diversification, and food independence index (Saliem et al. 2005; Ariani et al. 2007). In addition, food security can also be measured by using indicator of per capita energy consumption level per day (Ilham et al. 2006; Baldos et al. 2014; Wieck et al. 2014).

In this study, the measurement of food security performance is seen from macro dimension as a prerequisite for production, which in this case is represented by rice and rice production. Whereas, micro dimension required for adequacy, in this case is represented by rice consumption, rice prices, and energy consumption per capita.

Government is the main force as a driver of the economy, especially in developing countries (Ramey, 2011). It is impossible for a developing country like Indonesia to hand over the entire development process solely to the market mechanism. Fiscal policy is expected to have impact on all economic circles through (1) allocation of budgetary resources in the form of public expenditure (2) forms of financing in government expenditure, and (3) a balance between government expenditure and income (Todaro, 2000; Jhingan, 2000; Musgrave and Peggy, 1989; Stiglitz, 2000).

Government expenditures are very important to increase agricultural productivity (Gaiha et al. 2012). Ram (1986) and Taiwo (2011) state that government spending has a positive impact on economic growth. Landau (1986) who conducted a study on 104 countries found that there was a negative relationship between government spending and growth rates as measured by real GDP per capita. Similarly, Levine and Renelt (1992) found a negative relationship between government expenditure and GDP growth rate. Government expenditures must be evaluated and used as efficiently as possible to achieve maximum economic growth. One of the inefficiencies of government spending is due to corruption (Lopez and Galinato, 2007).

Government policies can be in the form of government expenditures such as granting subsidies, direct fertilizer assistance, superior seeds, open new lands, assistance of agricultural machinery and equipment, and improving other agricultural technologies. These government expenditure policies are useful to stabilize food prices and also beneficial to increase production in agricultural sector. The purpose of this study is to find out what factors affect food security and how the government policies influence food security and poverty in the province of Aceh.

\section{Research Method}

This research uses quantitative methods. The data used in this study are secondary data in the form of data panels, namely cross sections in 21 agriculturalbased districts in Aceh during the period of 2007-2016.

The analysis model in this study uses an econometric model with simultaneous equations, which then analyzed by 2SLS. This study examines food security from the aspect of food availability, i.e. grain production and rice production; food accessibility aspects, i.e. rice prices; and food utilization aspects, i.e. rice consumption and energy consumption.

The model built consists of two blocks, namely the input demand block which includes demand for fertilizer inputs and labor; and the block of food security includes rice production, rice prices, rice consumption, and energy consumption. For the purposes of estimating the model, the structural equation is made as follows:

\section{Block Input Demand}

Demand for Fertilizer

$\mathrm{FER}_{\mathrm{t}}=\mathrm{Y}_{0}+\mathrm{Y}_{1} \mathrm{Cge}_{\mathrm{t}}+\mathrm{Y}_{2} \mathrm{~W}_{\mathrm{t}}+\mathrm{Y}_{3} \mathrm{Ir}_{\mathrm{t}}+\mathrm{Y}_{4} \mathrm{Pf}_{\mathrm{t}}+\mathrm{Y}_{5} \mathrm{Pq}_{\mathrm{t}}+$ $\mathrm{Y}_{6} \mathrm{FER}_{\mathrm{t}-1}+\mathrm{e}_{1}$

Demand for labor

$L A B_{t}=Y_{0}+Y_{1} C e_{t}+Y_{2} W_{t}+Y_{3} I_{t}+Y_{4} P_{t}+Y_{5} P_{t}$ $+\mathrm{Y}_{6} \mathrm{LAB}_{\mathrm{t}-1}+\mathrm{e}_{2}$

\section{Commodity Market Block (Food Se- curity)}

Grain production (food availability)

$\mathrm{Qgab}_{\mathrm{t}}=\theta_{0}+\theta_{1} \mathrm{Cge}_{\mathrm{t}}+\theta_{1} \mathrm{~W}_{\mathrm{t}}+\theta_{2} \mathrm{Ir}_{\mathrm{t}}+\theta_{3} \mathrm{Pf}_{\mathrm{t}}+\theta_{4} \mathrm{Pq}_{\mathrm{t}}$ $+\theta_{5} \mathrm{Qg}_{\mathrm{t}-1}+\mathrm{e}_{3}$ 
Rice production (food availability)

Qber $_{\mathrm{t}}=62.74 \% \times \mathrm{Qgab}_{\mathrm{t}}$

Demand for rice (food utilization)

Dber $_{\mathrm{t}}=\varphi_{0}+\varphi_{1} \mathrm{YK}_{\mathrm{t}}+\varphi_{2}$ Pber $_{\mathrm{t}}+\varphi_{3} \mathrm{Pj}_{\mathrm{t}}+\varphi_{4}$ Dber $_{\mathrm{t}-1}+\mathrm{e}_{4}$

Market balance

Qber $_{\mathrm{t}}=$ Dber $_{\mathrm{t}}$

Rice price (food aceessibility)

Pber $_{\mathrm{t}}=\Phi_{0}+\Phi_{1} \mathrm{YK}_{\mathrm{t}}+\Phi_{2} \mathrm{Pj}_{\mathrm{t}}+\Phi_{3}$ Dber $_{\mathrm{t}-1}+\Phi_{4} \mathrm{Qber}_{\mathrm{t}}+$ $\Phi_{5}$ Pber $_{\mathrm{t}-1}+\mathrm{e}_{5}$

Energy consumption (food utilization)

Qeng $_{t}=\Pi_{0}+\Pi_{1} Y_{t}+\Pi_{2}$ Dber $_{t}+\Pi_{2}$ Pber $_{t}+\Pi_{4}$ Qeng $_{t-1}$ $+\mathrm{e}_{6}$

Endogenous Variables:

$\mathrm{LAB}_{\mathrm{t}}=$ Demand for labor input

FER $_{t} \quad=$ Demand for fertilizer input

$\mathrm{Qgab}_{\mathrm{t}}=$ Grain production

Qber $=$ Rice production

Dber $_{t}=$ Demand for rice

Pber $_{t}=$ Price of rice

Qeng $_{\mathrm{t}}=$ Energy consumption

Exogenous Variable

$\mathrm{W}_{\mathrm{t}} \quad=$ Wage

$\mathrm{Ir}_{\mathrm{t}} \quad=$ Interest rate

$\mathrm{Pq}_{\mathrm{t}} \quad=$ Price of grain

$\mathrm{Pf}_{\mathrm{t}} \quad=$ Price of fertilizer

$\mathrm{Pj}_{\mathrm{t}} \quad$ = Price of corn

$\mathrm{Yk}_{\mathrm{t}} \quad=$ Community income

$\mathrm{Cge}_{\mathrm{t}}=$ Government expenditure

Furthermore, historical simulations are used to see the impact of government policies on food security. Simulation analysis is conducted to determine the impact of policies on endogenous variables in the model. The purpose of simulation is to evaluate or review the policies. Therefore, historical simulations have been carried out for the past 5 years, from 2010-2014 with the scenarios of:

Simulation I = Increasing fertilizer prices to 10 percent Simulation II = Increasing government expenditure to10 percent

Simulation III $=$ Decreasing interest rates percent Simulation IV = Combination of increasing government expenditure to $10 \%$ and decreasing rice prices by $5 \%$.

\section{Realization of Government Expenditures on Agricultural Sector}

One way to see the ability of a region to deal with fiscal deficit is to look at the primary balance ratio, which is the ratio of total income minus total expenditure and interest expenditure divided by total income. The greater the primary balance surplus, the better the ability of the region to manage fiscal deficit (Pecapp, 2013). In aggregate, local governments in Aceh experienced a primary balance deficit of $7.54 \%$. It shows that Aceh government does not have enough liquidity to finance its fiscal deficit.

Based on the type of expenditure, if it is seen from the total amount, expenditure for development shows an increase of 20.26 percent; but in terms of percentage, it shows a decrease of 1.80 percent. It means that the expenditure in Aceh has been used more for the costs of routine expenditures rather than development expenditures. During the period of 1995-2015, the average routine expenditure was $52.58 \%$ while the expenditure for development was $47.42 \%$ (BPS: 1996-2016). The smaller amount of development expenditure compared to routine expenditures is a sample of illustration of the unfavorable budget setting for Aceh government.

The allocation of regional government expenditure for development in agricultural sector, which is the key to achieving food security, is still relatively small (Table 1 ). The high number of poverty in rural areas, where the majority of population lives in agricultural sector, turns out to be out of balance with the expenditure allocation for the agricultural sector itself. Although the revenue and expenditure of Aceh government showed a large increase during the period of 2008-2015, when it was viewed from the comparison of development expenditure allocation for agricultural sector, the total amount was still relatively small.

\section{Simulation of Increasing Fertilizer Prices Policy}

Some simulations are carried out both singly and in combination. A single simulation of an increase in fertilizer prices can be interpreted as the removal of subsidies by the government. This policy simulation has an impact on reducing fertilizer demand of $2.36 \%$, as well as decreasing labor absorption to $1.96 \%$ (Table 2).

Government should continue to maintain fertilizer subsidies because the increase of fertilizer prices is not only reducing fertilizer usage, but also lowering the labor absorption in agricultural sector and diminishing food availability. So far, subsidized fertilizers/ urea often disappear from the market due to fraud from certain parties. It makes farmers have difficulties in getting fertilizer, and in addition, such fraud causes an increase in fertilizer prices. 
Table 1

Revenues and Expenditures Realization of Aceh Government (1995-2015)

\begin{tabular}{|c|c|c|c|c|c|c|c|c|}
\hline \multirow[t]{2}{*}{ Year } & \multirow{2}{*}{$\begin{array}{r}\text { Revenue } \\
\text { (billion Rp) }\end{array}$} & \multicolumn{2}{|c|}{$\begin{array}{c}\text { Routine } \\
\text { Expenditure }\end{array}$} & \multicolumn{2}{|c|}{$\begin{array}{l}\text { Development } \\
\text { Expenditure }\end{array}$} & \multirow{2}{*}{$\begin{array}{c}\begin{array}{c}\text { Total } \\
\text { Expenditure }\end{array} \\
\text { (billion } \mathrm{Rp} \text { ) } \\
\end{array}$} & \multicolumn{2}{|c|}{$\begin{array}{l}\text { Agriculture } \\
\text { Expenditure }\end{array}$} \\
\hline & & (billion Rp) & $(\%)$ & (billion Rp) & $(\%)$ & & (billion Rp) & $(\%)$ \\
\hline 1995 & 228,7 & 87,5 & 39,02 & 136,8 & 60,98 & 224,2 & 3,0 & 1,35 \\
\hline 1996 & 224,7 & 108,5 & 49,19 & 112,1 & 50,81 & 220,5 & 2,5 & 1,15 \\
\hline 1997 & 299,5 & 149,1 & 50,20 & 147,8 & 49,80 & 296,8 & 4,2 & 1,43 \\
\hline 1998 & 253,7 & 168,7 & 66,72 & 84,1 & 33,28 & 252,8 & 3,2 & 1,25 \\
\hline 1999 & 295,3 & 187,1 & 68,61 & 85,6 & 31,39 & 272,7 & 2,7 & 1,01 \\
\hline 2000 & 494,8 & 296,4 & 62,32 & 179,3 & 37,68 & 475,6 & 5,9 & 1,23 \\
\hline 2001 & 795,3 & 414,8 & 56,26 & 322,4 & 43,74 & 737,2 & 17,0 & 2,31 \\
\hline 2002 & $1.171,4$ & 457,6 & 42,41 & 621,2 & 57,59 & $1.078,8$ & 23,4 & 2,17 \\
\hline 2003 & $2.918,6$ & $1.230,6$ & 47,99 & $1.333,7$ & 52,01 & $2.564,4$ & 122,9 & 4,79 \\
\hline 2004 & $2.633,5$ & $1.428,8$ & 54,26 & $1.204,7$ & 45,74 & $2.633,5$ & 66,6 & 2,53 \\
\hline 2005 & $4.963,5$ & $1.180,7$ & 23,79 & $2.917,4$ & 58,78 & $4.098,0$ & 59,6 & 1,45 \\
\hline 2006 & $5.554,6$ & $1.623,4$ & 29,23 & $3.920,7$ & 70,58 & $5.544,1$ & 44,6 & 0,80 \\
\hline 2007 & $4.081,1$ & $1.169,8$ & 28,66 & $2.911,3$ & 71,34 & $4.081,1$ & 30,4 & 0,74 \\
\hline 2008 & $8.673,5$ & $2.595,1$ & 29,92 & $4.316,8$ & 49,77 & $8.673,5$ & 39,7 & 0,46 \\
\hline 2009 & $10.766,5$ & $3.983,5$ & 37,00 & $5.354,5$ & 49,73 & $10.766,5$ & 188,9 & 1,75 \\
\hline 2010 & $11.514,9$ & $4.966,4$ & 43,13 & $4.787,7$ & 41,58 & $11.514,9$ & 250,5 & 2,18 \\
\hline 2011 & $11.162,8$ & $5.791,1$ & 51,88 & $4.463,2$ & 39,98 & $11.162,8$ & 275,1 & 2,46 \\
\hline 2012 & $11.071,2$ & $6.437,9$ & 58,15 & $4.124,0$ & 37,25 & $11.071,3$ & 295,1 & 2,67 \\
\hline 2013 & $13.169,6$ & $7.447,3$ & 56,55 & $5.067,8$ & 38,48 & $13.169,6$ & 281,1 & 2,13 \\
\hline 2014 & $14.173,6$ & $8.279,2$ & 58,41 & $5.020,5$ & 35,42 & $14.173,6$ & 328,5 & 2,32 \\
\hline 2015 & $15.799,1$ & $9.134,8$ & 57,82 & $6.579,2$ & 41,64 & $15.799,1$ & 453,6 & 2,87 \\
\hline $\begin{array}{r}\text { Rata- } \\
\text { rata }\end{array}$ & & & 52,58 & & 47,42 & & & 2,03 \\
\hline
\end{tabular}

This is very burdensome for food farmers who generally have capital constraints. Therefore, it is hoped that government will supervise the distribution of subsidized fertilizers to be on the right target and arrive on time when farmers need them.

However, the increase in fertilizer prices is only reduced grain production, rice production, and consumption rate down to 0.001 percent; while energy consumption did not show a decline, as well as the price of rice.
Table 2

Simulation of Increasing Fertilizer Price Policy

\begin{tabular}{lcll}
\hline $\begin{array}{l}\text { Endogenous } \\
\text { Variable }\end{array}$ & $\begin{array}{l}\text { Basic } \\
\text { Value }\end{array}$ & $\begin{array}{l}\text { Simulation } \\
\text { Value }\end{array}$ & $\begin{array}{l}\text { Change } \\
\text { (pers- } \\
\text { en) }\end{array}$ \\
\hline $\begin{array}{l}\text { FERt (fertilizer } \\
\text { demand) }\end{array}$ & 2047 & 1998.6 & -2.364 \\
$\begin{array}{l}\text { LABt (labour } \\
\text { demand) }\end{array}$ & 40566.8 & 39769.4 & -1.965 \\
$\begin{array}{l}\text { Qgabt (grain } \\
\text { production) }\end{array}$ & 79110.1 & 79109.1 & -0.001 \\
\hline
\end{tabular}




\begin{tabular}{lccc}
$\begin{array}{l}\text { Qbert (rice } \\
\text { suppluy) }\end{array}$ & 49633.7 & 496632.9 & -0.002 \\
$\begin{array}{l}\text { Dbert (rice } \\
\text { demand) }\end{array}$ & 49633.7 & 496632.9 & -0.002 \\
$\begin{array}{l}\text { Pbert (rice } \\
\text { price) }\end{array}$ & 4837.9 & 4837.9 & 0.000 \\
$\begin{array}{l}\text { Qengt (energy } \\
\text { consumtion) }\end{array}$ & 1060.5 & 1060.5 & 0.000 \\
\hline
\end{tabular}

\section{Simulation of Increasing Government Expenditures}

The single simulation of increased government spending in agricultural sector is only able to increase grain production to 2.51 percent, as well as rice production and consumption. This policy is also able to increase input demand, both in labor and fertilizer use inputs, respectively for 0.13 percent and 1.81 percent (Table 3 )

Table 3

Simulation of Increasing Government Expenditure Policy

\begin{tabular}{|c|c|c|c|}
\hline $\begin{array}{l}\text { Endogenous } \\
\text { Variable }\end{array}$ & $\begin{array}{l}\text { Basic } \\
\text { Value }\end{array}$ & $\begin{array}{l}\text { Simulation } \\
\text { Value }\end{array}$ & $\begin{array}{l}\text { Change } \\
\text { (in per- } \\
\text { cent) }\end{array}$ \\
\hline $\begin{array}{l}\text { FER }_{\mathrm{t}} \text { (fertilizer } \\
\text { demand) }\end{array}$ & 2047 & 2084.5 & 1.832 \\
\hline $\begin{array}{l}\mathrm{LAB}_{\mathrm{t}} \text { (labour } \\
\text { demand) }\end{array}$ & 40566.8 & 40619.8 & 0.131 \\
\hline $\begin{array}{l}\text { Qgab }_{t} \text { (grain } \\
\text { production) }\end{array}$ & 79110.1 & 81099.1 & 2.514 \\
\hline $\begin{array}{l}\text { Qber }_{t} \text { (rice } \\
\text { suppluy) }\end{array}$ & 49633.7 & 50881.6 & 2.514 \\
\hline $\begin{array}{l}\operatorname{Dber}_{\mathrm{t}} \text { (rice } \\
\text { demand) }\end{array}$ & 49633.7 & 50881.6 & 2.514 \\
\hline $\mathrm{Pber}_{\mathrm{t}}$ (rice price) & 4837.9 & 4837.9 & 0.000 \\
\hline $\begin{array}{l}\text { Qeng }_{\text {t }} \text { energy } \\
\text { consumption) }\end{array}$ & 1060.5 & 1060.5 & 0.000 \\
\hline
\end{tabular}

The single policy of increasing government expenditure to 10 percent has not been able to increase accessibility in food security and quality of consumption in food utilization. The price of rice and energy consumption has not changed with the increase in rice and rice production. This is because the price of rice is strongly influenced by rice consumption other than by production, which in research is seen from the ratio of production to consumption.

In theory, the increasing production will reduce prices, while the increasing consumption will increase prices. Since the increase percentage in production and consumption is the same, the price of rice is not changed. Therefore, the policy of increasing government spending in agricultural sector has not been able to increase food security in all three sides.

\section{Simulation of Decreasing Interest Rates}

The policy of reducing interest rates is analogous to capital assistance to farmers. Simulation of this policy has an impact on increasing demand for fertilizers for 1.25 percent, labour absorption for 1.39 percent, rice production for 1.94 percent, as well as enhancing rice production and consumption, (Table 4)

\section{Table 4}

\section{Simulation of Decreasing Interest Rates Policy}

\begin{tabular}{|c|c|c|c|}
\hline $\begin{array}{c}\text { End o gen o u s } \\
\text { Variable }\end{array}$ & $\begin{array}{l}\text { B a s i c } \\
\text { Value }\end{array}$ & $\begin{array}{c}\text { Simulation } \\
\text { Value }\end{array}$ & $\begin{array}{c}\text { Change } \\
(\%)\end{array}$ \\
\hline $\begin{array}{l}\mathrm{FER}_{\mathrm{t}} \text { (fertilizer } \\
\text { demand) }\end{array}$ & 2047 & 2072.7 & 1.255 \\
\hline $\begin{array}{l}\mathrm{LAB}_{\mathrm{t}} \text { (labour } \\
\text { demand) }\end{array}$ & 40566.8 & 41131.7 & 1.393 \\
\hline $\begin{array}{l}\text { Qgab }_{t} \text { (grain } \\
\text { production) }\end{array}$ & 79110.1 & 80642.2 & 1.937 \\
\hline $\begin{array}{l}\text { Qber }_{t} \text { (rice } \\
\text { suppluy) }\end{array}$ & 49633.7 & 50594.9 & 1.937 \\
\hline $\begin{array}{l}\operatorname{Dber}_{\mathrm{t}} \text { (rice } \\
\text { demand) }\end{array}$ & 49633.7 & 50594.9 & 1.937 \\
\hline Pber $_{t}$ (rice price) & 4837.9 & 4837.9 & 0.000 \\
\hline $\begin{array}{l}\text { Qeng }_{\mathrm{t}} \text { (energy } \\
\text { consumption) }\end{array}$ & 1060.5 & 1060.5 & 0.000 \\
\hline
\end{tabular}

Single simulation of this policy has not affected the decline of rice prices and the increase of energy consumption. Thus, it can be said that the policy of reducing interest rates is only effective in increasing the demand of input and food availability; while on food utilization, it is only able to increase rice consumption but unable to improve the quality of consumption because the value of energy consumption has not changed yet.

\section{Simulation of Increasing Government Expenditures and Rice Price Stabilization}

Combination of increasing government expenditure up to 10 percent and a decrease of rice prices to 5 percent has the greatest impact on all endogenous variables in the model. This combination of policies has an impact on increasing demand for fertilizer up to 1.83 percent, employment increase for 0.13 percent, and grain production increase for 2.51 percent. Furthermore, this combination also increases rice production 
and consumption to $2.51 \%$ In addition, by applying the policy of decreasing rice prices, energy consumption has increased to $2.34 \%$.

\section{Table 5 \\ Combination Simulation of Increasing Government Expenditures and Decreasing Rice Prices Policies}

\begin{tabular}{|c|c|c|c|}
\hline $\begin{array}{l}\text { Endogenous } \\
\text { Variable }\end{array}$ & $\begin{array}{l}\text { Basic } \\
\text { Value }\end{array}$ & $\begin{array}{l}\text { Simulation } \\
\text { Value }\end{array}$ & $\begin{array}{l}\text { Change } \\
\text { (percent) }\end{array}$ \\
\hline $\begin{array}{l}\mathrm{FER}_{\mathrm{t}} \text { (fertilizer } \\
\text { demand) }\end{array}$ & 2072.7 & 2084.5 & 1.832 \\
\hline $\begin{array}{l}\mathrm{LAB}_{\mathrm{t}} \text { (labour } \\
\text { demand) }\end{array}$ & 41131.7 & 40619.8 & 0.131 \\
\hline $\begin{array}{l}\text { Qgab }_{t} \text { (grain } \\
\text { production) }\end{array}$ & 80642.2 & 81099.1 & 2.514 \\
\hline $\begin{array}{l}\text { Qber }_{t} \text { (rice } \\
\text { suppluy) }\end{array}$ & 49633.7 & 50881.6 & 2.514 \\
\hline $\begin{array}{l}\text { Dber }_{\text {t }} \text { (rice } \\
\text { demand) }\end{array}$ & 49633.7 & 50881.6 & 2.514 \\
\hline $\begin{array}{l}\operatorname{Pber}_{\mathrm{t}} \text { (rice } \\
\text { price) }\end{array}$ & 4837.9 & 4596 & -5.000 \\
\hline $\begin{array}{l}\text { Qeng }_{\mathrm{t}} \text { (energy } \\
\text { consumption) }\end{array}$ & 1060.5 & 1085.3 & 2.339 \\
\hline
\end{tabular}

The combination of these policies is considered to be the most effective way in increasing food security in terms of availability, accessibility, and utilization. In addition, this combination is also effective in increasing input demand and employment in agricultural sector.

\section{Impact of the Policies on Food Secu- rity, Absorption of Labour \& Poverty}

Based on the information above, it is known that single policy is not effective in increasing food security on all sides and also has no impact on poverty. The combination of increased government spending and rice price stabilization is the most effective policy to improve food security in terms of availability, accessibility, and utilization. In addition, this combination is also effective in increasing input demand and employment in agricultural sector. Based on simulation results described in Table 2 to Table 5, the recapitulation can be seen in Table 6.

\section{Table 6 \\ Recapitulation of Simulation in Endogenousous Variable Changes (\%)}

\begin{tabular}{lllll}
\hline $\begin{array}{l}\text { Endogenous } \\
\text { Variable }\end{array}$ & $\begin{array}{l}\text { Simula- } \\
\text { tion I }\end{array}$ & $\begin{array}{l}\text { Simula- } \\
\text { tion II }\end{array}$ & $\begin{array}{l}\text { Simula- } \\
\text { tion III }\end{array}$ & $\begin{array}{l}\text { Simu- } \\
\text { lation } \\
\text { IV }\end{array}$ \\
\hline $\begin{array}{l}\text { FER } \\
\text { demand) }\end{array}$ & -2.364 & 1.814 & 1.255 & 1.832 \\
$\begin{array}{l}\text { LAB }_{\mathrm{t}} \text { (labour } \\
\text { demand) }\end{array}$ & -1.965 & 0.132 & 1.393 & 0.131 \\
& & & &
\end{tabular}

\begin{tabular}{lllll} 
Qgab $_{t}$ (grain & -0.001 & 2.515 & 1.937 & 2.514 \\
production) & & & & \\
$\begin{array}{l}\text { Qber }_{t} \text { (rice } \\
\text { suppluy) }\end{array}$ & -0.002 & 2.515 & 1.937 & 2.514 \\
$\begin{array}{l}\text { Dber }_{t} \text { (rice } \\
\text { demand) }\end{array}$ & -0.002 & 2.515 & 1.937 & 2.514 \\
$\begin{array}{l}\text { Pber }_{t} \text { (rice } \\
\text { price) }^{\text {Qeng }} \text { (energy } \\
\text { consumption) }\end{array}$ & 0.000 & 0.000 & 0.000 & -5.000 \\
\hline
\end{tabular}

\section{Description:}

Simulation I : Increasing of fertilizer prices up to $10 \%$ Simulation II:Increasing of government expenditure to $10 \%$

Simulation III : Decreasing of interest rates \%.

Simulation IV : Combination of increasing government expenditure to $10 \%$ and decreasing of rice prices to $5 \%$.

The simulation results above show that to increase food security in all sides (food availability, consumption, and employment), the government can't do it with a single policy, but need to do a combination of fiscal policy and price stabilization policy. This is because the price of rice in the market does not follow the perfect competition market structure. The price of rice is more determined by traders and resulted in relatively large marketing margin between traders and farmers as producers, which seems only profitable for traders. This is due to the malfunction of Bulog (national logistic agency) as price stabilizer. Bulog purchased grain not directly from farmers, but from mills. Thus, the government purchase (through Bulog) is not to support farmers, but to support the miller. Because of that, the role of Bulog, which has switched since $1997 / 1998$, is only as a manager of rice supply. In 2003, Bulog has changed its status to public company and it needs to be revised again. It must function as a food price stabilizer because the price of rice so far has not been fully released to the market.

Government expenditure in agriculture is still relatively small compared to the enormous potential and population involved in this sector. In 2017, 44.62 percent of Aceh's population was still relied on agricultural sector. Moreover, the people involved in agricultural sector generally live in poverty, especially the food crop sub-sector. Lack of capital and the low price of grain have become the main obstacles for farmers in carrying out their farming. If the government does not seriously pay attention to increasing farmers' income, it is feared that the conversion of agricultural land will be even greater. This is because farmers are not interested in 
producing due to matters mentioned earlier. Therefore, besides maintaining fertilizer subsidies, government are expected to increase their spending through many programs, such as programs to improve farmers' welfare, programs to improve food security, programs to increase marketing and agricultural production, and programs to increase the use of agricultural technology and processing products. In addition, the government must also realize that Rastra (rice for the poor program) is not assistance to reduce number of poor people, but only to fulfill the food needs for the poor. Government should be consistent in empowering the poor, especially in rural areas, either by providing assistance in the form of tools and venture capital or opening new lands for farmers who do not have one.

On the other hand, government should give full control over the running of such programs so that such they will function as they should. Additionally, there are the needs to integrate all parties to avoid overlapping programs. Programs should not only be output-oriented, but more importantly have the capability to produce outcomes which can improve people's well-being.

\section{Conclusion}

The simulation shows that the increase of government expenditure can enhance food availability. However, to improve accessibility and utilization of food, government need to combine their expenditure policy with rice price stabilization policy. Meanwhile, fiscal policy in the form of fertilizer subsidies needs to be maintained considering that fertilizer is one of the important inputs for the sustainability of rice farming. If government removes fertilizer subsidies, not only it has an impact on decreasing the amount of fertilizer demand but would also decrease number of employment in agricultural sector.

Increasing food security can reduce the amount of poverty. This poverty alleviation is done through increasing food production which would rise farmers' income and widely open their accesses to food. Affordable food prices for consumers would not only increase the consumption, but also reduce the expenditure on food. Fulfilling people's nutrition is a great way to increase level of health and work productivity, which in the end will also increase their income.

Budget and program allocations must be carried out effectively and efficiently. The government may have to reduce the cost of their official travels, fees/grants, and other ineffective routine expenses. In addition, it is necessary to have a good financial management so that the realization of budget can be used on time and on target. Delay in budget realization can impede the development. Capital assistance for farmers, especially poor farmers, needs to be increased to avoid debts from middlemen. The government can bear a portion of farmers' production costs to produce food. For this reason, the cooperation with banks or other financial institutions is needed as a provider of working capital assistance. The distribution of working capital involves farmer groups, religious leaders, community leaders, and cooperatives at village level. It is very important to regulate such assistance utilization in order to avoid the misuse.

\section{References}

Anriquez, G. (2007). Rural Development and Proverty Reduction: is Agriculture Still The Key. Jurnal of Agriculture and Development Economics. Vol. 4, No. 1, (5-46)

Ariani, M., H.P. Saliem, G.S. Hardono and T.B. Purwatini. (2007). Wilayah Rawan Pangan dan Gizi Kronis di Papua, Kalimantan Barat dan Jawa Timur. Pusat Analisis Sosial Ekonomi dan Kebijakan Pertanian, Departemen Pertanian, Bogor.

BPS. (1996-2016). Statistik Keuangan Daerah. Jakarta.

Baldos, U. L. C. and Thomas, W. H. (2014). Global Food Security in 2050: The Role of Agriculture Productivity and Climate Change. Australian Journal of Agriculture and Resources Economics. (58), 554-570.

Christiaensen, L., Demery, L., \& Kuhl, J. (2011). The (evolving) role of agriculture in poverty reduction-An empirical perspective. Journal of Development Economics, 96(2), 239-254.

FAO (1996). Rome Declaration of the World Food Security and World Food Summit Plan of Action. FAO, Rome.

Gaiha R, Katsushi S. Imai, Ganesh Thapa, and Woojin Kang (2012). Fiscal Stimulus, Agriculture Growth and Poverty in Asia. The world Economy. 35 (6). 713-739.

Ibrahim, B., M, Rituhardoyo, S., and Setiadi, (2016). Characteristics of Poverty in Rural Commonities of Gold Mining District Area West Sumbawa. Mimbar, 32 (1), 163-174 
Ilham, N, Hermanto S, dan D.S Priyarsono, (2006). Efektivitas Kebijakan Harga Pangan terhadap Ketahanan Pangan. Jurnal Agro Ekonomi. 24(2). 157-177.

Irz, X., Lin, L., Thirtle, C., \& Wiggins, S. (2001). Agricultural productivity growth and poverty alleviation. Development policy review, 19(4), 449-466.

Jhingan, M.L. (2000). Ekonomi Pembangunan dan Perencanaan, Raja Grafindo Persada, Jakarta.

Landau, D. L. (1986). Government and economic growth in the less developed countries: an empirical study for 19601980. Economic Development and Cultural Change, 35-75.

Levine, R., \& Renelt, D. (1992). A sensitivity analysis of cross-country growth regressions. American economic review, 82(4), 942-963.

Lopez, R., \& Galinato, G. I. (2007). Should governments stop subsidies to private goods? Evidence from rural Latin America. Journal of Public Economics,91(5), 1071-1094.

Mogues, T., Yu, B., Fan, S., \& McBride, L. (2012). The impacts of public investment in and for agriculture: Synthesis of the existing evidence. ESA Working Paper No 12-0. Agricultural Development Economics Division. Food and Agriculture Organization of the United Nations.

Musgrave, R.A and Peggy, (1989). Public Finance in Theory and Practice. McGrawhill Book Company. New York.

Pecapp, 2013. Analisis Belanja Aceh 2013. www.belanjapublikaceh.org.

Pusdatin Kementrian Pertanian RI, (2015). Statistik Penduduk dan Kemiskinan sektor Pertanian. Pusat Data dan Informasi Pertanian.

Rada, N. E., Buccola, S. T., \& Fuglie, K. O. (2011). Government policy and agricultural productivity in Indonesia. American journal of agricultural economics, 93(3), 863-880.

Ram, R. (1986). Government size and economic growth: A new framework and some evidencefrom cross-section and time-series data. American Economic Review, 76(1), 191-203.

Ramey, V. A. (2011). Can government purchases stimulate the economy? Journal of Economic Literature, 49(3), 673-685.
Ravallion, M., \& Datt, G. (1996). How important to India's poor is the sectoral composition of economic growth? The World Bank Economic Review, 10(1), $1-25$.

Saliem, E.M. Lokollo, M. Ariani, T.B. Purwantini, and Y. Marisa. (2005). Analisis Ketahanan Pangan Tingkat Rumah Tangga dan Regional. Pusat Penelitian dan Pengembangan Sosial Ekonomi Pertanian, Balai Penelitian dan Pengembangan Pertanian, Bogor.

Siregar, H and Wahyuniarti, D. (2008). Dampak Pertumbuhan Ekonomi Terhadap Penurunan Jumlah Penduduk Miskin. http://pse.litbang.go.id/ind.

Stiglitz, J.E. (2000). Economic of The Public Sector. $3^{\text {rd }}$ Edition. New York: W.W. Norton and Company.

Suryahadi, A., \& Hadiwidjaja, G. (2011). The role of agriculture in poverty reduction in Indonesia. In Centre for Strategic Economic Studies-Australian Centre for International Agricultural Research International Workshop on the Role of Agriculture in Poverty Reduction, Melbourne.

Taiwo, M. (2011). Goverment Expenditure and Economics Development: Empirical Evidence From Nigeria. European Journal of Business and Management. 3(9).18-29.

Thomson, A. (2004). Agriculture, Growth and Proverty Reduction. Departement for Internasional Development Working Paper, Oktober 2004.

Timmer, C.P. (2004). Food Security and Economic Growth : An Asian Perspective. H.W. And Memorial Lecture. Australian National University.

Timmer, P. (1995). Getting Agriculture Moving: Do Market Provide The Right Signal?. Food Policy 20(5): 455-472.

Todaro, Michael P, Stephen C. Smith. (2000). Pembangunan Ekonomi. (Jilid 1) Jakarta: Erlangga.

Wieck, C., Rudloff, B., Heucher, A., \& Heckelei, T. (2014). Agri-investments and public spending in selected vulnerable countrieswill they contribute to reduce food insecurity?. Discussion Paper 2014 : 1.

World Bank, (2007). World Development Report 2008. Agriculture for Development Washington DC. 